\title{
Effect of Coffee Consumption on the Incidence and Severity of Post Dural Puncture Headache among Post Cesarean Section Women
}

\author{
Wafaa Taha Ibrahim Elgzar*, Violet Nicola Ghattas \\ Obstetric and Gynecologic Nursing, Faculty of Nursing, Damanhor University, Egypt \\ *Corresponding Author \\ Wafaa Taha Ibrahim Elgzar
}

Email: wafaa.elgzar@nur.dmu.edu.eg,wafaa22006@yahoo.com

\section{Article History}

Received: 14.11.2019

Accepted: 21.11.2019

Published: 14.12 .2019

\begin{abstract}
Background: Post-Dural Puncture Headache (PDPH) is the most prevalent complication after lumbar puncture (LP), with reported frequency varying from $6 \%$ to $36 \%$ of patients. Aim: investigate the effect of coffee consumption on the incidence and severity of post-dural puncture headache among post cesarean section women. Research design: Randomized controlled clinical trial. Setting: Postpartum department at Damanhour National Medical institute/ Elbehira governorate. Egypt. Sample: 120 women undergoing elective caesarean section under spinal anesthesia were randomly allocated to study and control group using randomization block. Tools: three tools were used for data collection. Structured interview schedule to collect basic data, headache assessment tool (visual analogue pain scale, short-form McGill pain questionnaire, assessment of headache aggravating and alleviating factors) and physical activities limitation questionnaire. Results: The incidence and severity of PDPH is higher among control more than coffee group. While, the maximum incidence of continuous PDPH occurs in the third post-operative day among control group (40\%) compared to only $13.3 \%$ among intervention. Both VAS and McGill Pain score are statistically higher among control compared to intervention group over several time points. PDPH is aggravated by light, noise, standing, moving and siting in control groups than intervention groups. Laying down, closing eyes, drinking fluids are major soothing factors for both groups. The highest percentages of coffee group had no effect on activity of daily living compared to control group. The differences between the two groups are statistically significant intergroup, intragroup and for group time interactions. Conclusion: Coffee decreased both incidence and severity of PDPH and increased tolerance of post Cs activities. Recommendations: Oral coffee may be added to post Cs nursing care protocols to decrease PDPH incidence, severity and enhancing early physical activities.
\end{abstract}

Keywords: Post-Dural puncture headache, caesarian section, spinal anesthesia, coffee.

\section{INTRODUCTION}

Cesarean section (CS) is very important procedure that save mother and neonate if there is contra indications for vaginal delivery. The world health organization stated that CS rate more than $10 \%$ did not contribute to the reduction of maternal mortality. Egypt demographic and health survey 2014 had reported a sharp surge in CS rate that reach $52 \%$ of births [1].Generally, spinal anesthesia is preferred than general anesthesia in case of CS. The main aim of using spinal anesthesia is to avoid complications of general anesthesia for both mother and fetus. General anesthesia is commonly used in case of emergency situation depending on the mother and fetus wellbeing. Consequently in almost all elective CS spinal anesthesia is chosen to minimize the side effects and improve post-operative recovery [2].

CS under spinal anesthesia is commonly associated with abdominal operation risks. These including wound infection, adhesions, bleeding, hernia and tubal adhesions. Other temporal discomforts including incisional pain, after pain, post spinal hypotension and Post-Dural Puncture Headache (PDPH) [3]. Post-Dural Puncture Headache (PDPH) is the most prevalent complication after lumbar puncture (LP), with reported frequency fluctuating between $6 \%$ and $36 \%$. Historically, PDPH was firstly described by August Bier (1861-1949). He reported the recurrent incidence of this phenomenon among his patients. Surprisingly, he suffered from PDPH himself when he conducted an operation under spinal anesthesia [4].

Copyright @ 2019: This is an open-access article distributed under the terms of the Creative Commons Attribution license which permits unrestricted use, distribution, and reproduction in any medium for non commercial use (NonCommercial, or CC-BY-NC) provided the original author and source are credited. 
Post-Dural Puncture Headache (PDPH) is bifrontal and occipital pain that becomes worse when moving head, upright position, noise, light and strain. Nausea, vertigo, tinnitus, diplopia and vomiting are known as warning signs that followed by PDPH. Furthermore, the soothing factors for PDPH is lying down without pillow and dark, quite environment. Time of its first occurrence ranged from several hours to days after dural puncture but mostly in $90 \%$ of cases it takes place during the first 5 days post-operative and specifically in the first three days. Usually, PDPH is self-limited at about 5-7 days among 80 to $85 \%$ of cases. It rarely lasts longer than two weeks [5].

The cause PDPH is still to be vague and unsure. The most accepted hypothesis of its occurrence is the low cerebrospinal fluid (CSF) pressure after spinal puncture. Leakage of CSF through a dural and arachnoid tear generated by the puncture may temporally exceeds its output resulting in low CSF pressure. The constant CSF leakage over days cause some strain on the central nervous system (pain-sensitive structure stretching) resulting in PDPH. Another hypothesis is that, PDPH occurs due to the cerebral vasodilation following lumber puncture resulting in cerebral hypotension [6]. Although, PDPH have unknown and vague causes but some factors are reported to be linked with its incidence and severity. These factors can be classified as modifiable and nonmodifiable one. Modifiable factors include needle size and shape of its tip, number of trials, dural fiber bevel placement, lumber puncture method, type of anesthetic solution and anesthetist skills or experience. The non-modifiable factors include age, sex, PDPH history, and pregnancy [7].

In general, PDPH is more prevalent in women than men are in the same age group. According to Lybecker et al., Women have double risk to suffer from PDPH than male. They reported that some physiological and psychological factors inside the female's bodies made them at higher risk. Women appear to be processing nociceptive data differently from males, demonstrating more sensitivity to painful stimuli that promotes the process of core sensitization. In addition, pain perception in females is higher than males [8].

Some studies reported that older women have more risk to develop PDPH. The condition become worse with parturient due to many factors. Those factors includes but not limited to secondary dehydration due to postpartum diuresis, blood loss, hormonal imbalance, increased serum estrogen, intra-abdominal imbalance, and peri-dural pressure. Furthermore, the elevated estrogen level results in systemic vasodilation in the blood vessels including cerebral blood vessels. Consequently parturient is the highest risk group for PDPH, with an incidence up to 38\% [8, 9]. Although PDPH pathophysiology is uncertain, various treatments for this disorder are considered to be efficient. Medical treatment includes different types of analgesia including opioids and antiemetic, epidural saline epidural dextran, blood patch and caffeine injection [9, 10].Nursing intervention for PDPH including vigorous hydration by oral and intravenous fluids, bed rest without pillow to increase blood supply to the head, and caffeine drinking $[9,10]$.

In 1949, caffeine was first recorded as a PDPH therapy. Caffeine is central nervous system stimulant and is believed to treat PDPH by causing cerebral vasoconstriction. Doses from 300 to $500 \mathrm{mg}$ is considered safe and therapeutic. Caffeine can be administrated intravenous, intramuscular and oral. Where, oral intake of caffeine is more safe, easy and acceptable by large population. Caffeine is used for treatment of multiple headache situations and proved to be helpful. It can also be used to manage neonatal respiratory depression and in electroconvulsive therapy [11, 12] Caffeine may generate immediate adjuvant analgesic characteristics in many pain circumstances [13]. Itis known to cause cardiovascular vasoconstriction. This effect may be helpful to relieve postprandial hypotension and other hypotention conditions as PDPH [14]. Blocking of methylxanthine sensitive adenosine receptors is the mechanism of action presently adopted by caffeine. Coffee is the most popular drink of caffeine. Other sources include cola and dark chocolate. Coffee is the most popular drink used around the world. It is used to improve mood, manage fatigue, promote wakefulness, and enhance attention. Other medical benefits had been discovered for coffee as protect against Parkinson's and Alzheimer disease due to its stimulant effect [15]. In addition, coffee has cardiovascular protective effect. It decrease the risk for stroke and act as antifibrotic agent [16]. It also have the ability to improve liver functions and protect against liver diseases [17].

Any way coffee is considered to be safe and have health benefits if used in moderate quantities and not excised daily recommended dose (about 5 cups of coffee). Heavy coffee use is associated with numerous unpleasant symptoms such as restlessness, anxiety, insomnia, nervousness and elevated blood pressure. Practice guidance on secure coffee consumptionis necessary [18]. Post cesarean women has numerous complains that has been exaggerated by PDPH. It can decrease pain tolerance, increase anxiety, tension and increase the severity of postpartum blues. PDPH also can limit her ability to care for herself and her newborn. If the nurse can find natural, simple, available method to relive such PDPH, it will help to alleviate the women suffering. This study is essential to clarify the role played by nurse in post-operative care, headache prevention and therapy after dural puncture by encouraging post-operative use of coffee. Ultimately, mothers will suffer less from PDPH, resulting in early ambulation and early role accommodation and improve post-partum outcomes.

\section{Materials ANd Method MATERIALS}

Aim: Investigate the effect of coffee consumption on the incidence and severity of post dural puncture headache among post cesarean section women. 


\section{Research Hypothesis}

H1: Post Cs women who consume $300-500 \mathrm{mg}$ of coffee daily exhibit lower incidence and severity of PDPH and more tolerance of daily living activities than control group.

H0: Post Cs women who consume $300-500 \mathrm{mg}$ of coffee daily exhibit the same incidence and severity of PDPH and daily living activities tolerance as control group.

\section{Research design: Randomized controlled clinical trial.}

Setting: This study was done at postpartum department at Damanhour National Medical institute allied to ministry of health/ Elbehira governorate/ Egypt.

\section{Sample}

A purposive sample of 120 women undergoing Caesarean section were considered as potential subjects. Inclusion criteria were normal pregnancy, elective cesarean section with spinal anesthesia, aged 20-45 years, free medical history, and accepted to participate in the study. The women who had any intra or post-operative complications or who usually consume more than three cups of coffee per day were excluded from the study.

The sample size was estimated based on the Epi-Info 7 program using the following parameters: Target population 720 in the last year; Expected frequency $p=50 \%$; Acceptable error $=10 \%$; Confidence coefficient $=95 \%$; Sample size $=120$

Study participant were randomly assigned to either study or control group using randomization block technique. Randomization block was manually done according to the following steps:

- The researchers prepared a list contain the numbers from one to 120

- Another separate paper for each number from 1 to 120 was prepared.

- Each separate paper was rolled up until the number is unseen at that time all papers were mixed and put in a ball.

- The 120 pieces of papers were randomly and blindly divided into 6 blocks each one comprises 20 random numbers.

- From each block, 10 random numbers were picked up blindly to be assigned to the study group and the residual 10 to the control group.

- Then recordkeeping of the cases order was done on the formerly prepared list (Before each number the investigator write the word case or control) to be considered during data collection. A total of 60 women were cases and 60 were control.

Tools: Five tools were used for data collection.

\section{Tool one: structured interview schedule:}

It was developed to collect basic data. It contains three parts. The First contain socio-demographic data such as name, phone number, age, level of education, occupation, current residence, monthly income and marital status. The second contains obstetric history such as: gravidity, parity, gestational age at delivery, and number of antenatal visits. The third part concerned with analgesia type, dose and frequency.

\section{Tool two: headache assessment tool.}

\section{Part l: Visual analogue pain scale (VAS) to assess pain intensity [19]:}

It is a 10 points numerical scale, matching to the degree of headache. Where 0 indicates no pain, 1 up to 3 indicates mild pain, 4 up to 6 indicates moderate pain, 7 up to 9 indicates severe pain. Finally 10 indicate the worst unbearable pain. The parturient was asked to select from that 10 points numerical continuum the number that corresponds to her perceived PDPH intensity. Each day in the period of data collection the women is asked to assess severity and duration of headache either continues or intermittent.

\section{Part II: The short-form McGill Pain Questionnaire [20]:}

It was settled by Melzack1987 [19] to evaluate both the quality and intensity of subjective pain. The scale is adopted and translated to Arabic language. The translated form contains Pain Rating Index (PRI) (Sensory and affective descriptors). It composed of 10 items that describe both sensory ( 6 items) and affective sensations (4 items) associated with headache. Each item is rated as (none $=0)$, (mild=1), (moderate $=2$ ) and (sever $=3$ ). The total score for the 10 items ranged from 0 to 30 .

\section{Part III: assessment of PDPH aggravating and alleviating factors.}

This part was developed by the researchers to assess headache aggravating factors as noise, light, speech, standing, ........etc. and alleviating factors as rest, closing eyes, eating, ...etc.

\section{Tool three Physical activities limitation Questionnaire}

It was developed by the researchers to assess the limitation of physical activities due to PDPH after cesarean section. It consists of 6 items (sitting in bed, standing up, walking, performing personal hygiene, and using a toilet) which ranked as: $0=$ easy done, $1=$ done with difficulties, $2=$ done with help, and $3=$ cannot done. The total scores ranged from 0 to 18 . 


\section{METHODS}

1. An official permission was obtained from nursing college Damanhour University. Then it was directed to the accountable authority in Damanhour National Medical institute to obtain their permission to carry out the research after clarification of its aim and scientific background.

2. Tool one and three were developed by the researchers after reviewing the related literatures. Tool two were adopted and translated into Arabic language. All tools were revised by a board of five professors in the field of obstetrics and gynecology and one in the biostatistics to guarantee content validity. Cronbach's alpha for tool 2 , and tool 3 were $r=0.73$, and 0.81 respectively.

3. After the completion of the tools, a pilot study was done on 20 women who undergoing CS to ensure clarity and applicability of the tools.

4. Ethical consideration: Each woman in the study and control groups was interviewed alone in complete privacy in order to explain the study purpose, take her consent to participate, ensure her right to refuse participation or withdraw from the study at any time without any consequences. The woman was assigned to study or control group based on the predetermined randomization blocks.

- The researchers interviewed each woman individually on the day before the operation for about 30 minutes; the researchers introduced themselves, and explained the study purpose, then oral consent was obtained for participation in the study. During this interview tool 1 (part 1 and 2) was collected from the woman.

- The researcher contracted the woman to participate on the study during the postpartum period.

\section{Hours after the Operation}

- For the study group the researchers provide each woman with a packet contain $500 \mathrm{mg}$ of instant coffee. In the hospital the researcher offered the woman $200 \mathrm{ml}$ cup of instant coffee 8 hours after surgery. Then she was instructed to consume three cups per day. It is preferred to be at the day in order not to interfere with sleeping time. Each $200 \mathrm{ml}$ cup of instant coffee $=160 \mathrm{mg}$ caffeine. (21) A total of $480 \mathrm{mg}$ of caffeine was consumed per day. The type of coffee was fixed and no additive except sugar were allowed. The therapeutic dose from 300 up to $500 \mathrm{mg}$ per day. During hospitalization, coffee consumption was ensured by the in duty nurse. The researcher used tool two and three to asses PDPH incidence and severity. Therefore, the study group received coffee with the routine hospital care. After discharge both coffee consumption follow up and headache assessment was done by the researcher using phone interview. Follow up for coffee consumption and headache assessment was done for one week post-operative

- The control group received routine hospital care only. The routine hospital care include bed rest without pillow and scheduled analgesic (Morphine). The same follow up was done for control group by the researchers.

- Data was collected over a period of eight months from the beginning of January until end of August 2019.

5. After data collection was completed, it was feed to SPSS version 24 to analyze it. Data was coded and categorized, number, percentage, mean and stander deviation were used to describe the basic data. Chi-Square, Fisher Exact Test and T-test were used to test the differences between coffee and control groups. 


\section{RESULTS}

Table-1: Percent distribution of the study participants according to their demographic characteristics and reason for CS

\begin{tabular}{|c|c|c|c|c|c|c|}
\hline \multirow[t]{2}{*}{ Demographic characteristics } & \multicolumn{2}{|c|}{ Intervention group } & \multicolumn{2}{|c|}{ Control group } & \multirow[t]{2}{*}{ Significant test } & \multirow[t]{2}{*}{$P$ value } \\
\hline & $N=60$ & & $\mathrm{~N}=60$ & $\%$ & & \\
\hline \multicolumn{7}{|l|}{ Age } \\
\hline$\leq 20$ year & 13 & 21.7 & 10 & 16.7 & $X^{2}=0.484$ & $P=0.487$ \\
\hline $21-35$ year & 47 & 78.3 & 50 & 83.3 & & \\
\hline Mean $\pm S D$ & \multicolumn{2}{|c|}{$23.65 \pm 4.149$} & \multicolumn{2}{|c|}{$25.08 \pm 3.997$} & $t=0.576$ & $P=0.566$ \\
\hline \multicolumn{7}{|l|}{ Working status } \\
\hline Employee & 31 & 51.7 & 26 & 43.3 & $X^{2}=0.835$ & $P=0.361$ \\
\hline Housewife & 29 & 48.3 & 34 & 56.7 & & \\
\hline \multicolumn{7}{|l|}{ Education } \\
\hline Illiterate/ read \& write & 13 & 21.7 & 10 & 16.7 & & \\
\hline Primary \& preparatory & 22 & 36.7 & 19 & 31.7 & FET $=1.429$ & \\
\hline Secondary & 21 & 35.0 & 27 & 45.0 & & $P=0.729$ \\
\hline University/Post & 4 & 6.7 & 4 & 6.7 & & \\
\hline \multicolumn{7}{|l|}{ University } \\
\hline \multicolumn{7}{|l|}{ Marital status } \\
\hline Married & 55 & 91.7 & 58 & 96.7 & & \\
\hline Divorced & 4 & 6.7 & 1 & 1.7 & FET $=1.972$ & $P=0.521$ \\
\hline Widow & 1 & 1.7 & 1 & 1.7 & & \\
\hline \multicolumn{7}{|l|}{ Residence } \\
\hline Rural & 33 & 55.0 & 40 & 66.7 & $X^{2}=1.71$ & $P=0.262$ \\
\hline Urban & 27 & 45.0 & 20 & 33.3 & & \\
\hline \multicolumn{7}{|l|}{ Monthly income } \\
\hline Enough and save & 4 & 6.7 & 3 & 5.0 & & $P=0.521$ \\
\hline Enough & 15 & 25.0 & 19 & 31.7 & $\mathrm{FET}=1.972$ & \\
\hline Not enough & 41 & 68.3 & 38 & 63.3 & & \\
\hline \multicolumn{7}{|l|}{ Reason for CS } \\
\hline Pregnancy complications & 15 & 25.0 & 9 & 15.0 & & $P=0.332$ \\
\hline Previous CS & 33 & 55.0 & 40 & 66.7 & $X^{2}=2.215$ & \\
\hline Woman choice & 12 & 20.0 & 11 & 18.3 & & \\
\hline
\end{tabular}

According to Table-1, no statistically significant differences are found between the two groups' socio-demographic characteristics. Furthermore, more than three-quarters $(78.3 \& 83.3 \%)$ of intervention and control groups respectively were $21-35$ years old. In addition, $36.7 \% \& 35 \%$ of the intervention group are primary \&preparatory and secondary education, respectively, compared to $31.7 \% \& 45 \%$ of the control group. Approximately one- half of the intervention (55\%) and control (66.6\%) groups are rural area residents.It is found that $68.3 \%$ of the intervention and $63.3 \%$ control groups monthly income is not enough. Finally $55 \%$ of intervention group have previous Cs compared to $66.7 \%$ of the control group,

Table-2: Mean and stander division of the study participants according to their obstetrical history and post-operative vital signs

\begin{tabular}{|c|c|c|c|c|}
\hline $\begin{array}{l}\text { Obstetrical history and post-operative vital } \\
\text { signs }\end{array}$ & $\begin{array}{l}\text { Intervention group }(\mathrm{N}=60) \\
\text { Mean } \pm \mathrm{SD}\end{array}$ & $\begin{array}{l}\text { Control group }(\mathrm{N}=60) \\
\text { Mean } \pm \mathrm{SD}\end{array}$ & t test & $P$ value \\
\hline Gravidity: & $1.83 \pm 0.717$ & $2.02 \pm 0.692$ & -1.329 & 0.186 \\
\hline Parity & $1.72 \pm 0.739$ & $1.90 \pm 858$ & -1.255 & 0.212 \\
\hline Gestational age & $38.00 \pm 0.823$ & $37.88 \pm 0.804$ & 0.785 & 0.434 \\
\hline Numbers of previous CS & $1.32 \pm 1.112$ & $1.60 \pm 1.224$ & -1.327 & 0.187 \\
\hline Number of antenatal visits during current pregnancy & $13.12 \pm 1.367$ & $12.34 \pm 1.652$ & 0.066 & 0.947 \\
\hline Systolic BP 6h post CS & $116.42 \pm 7.853$ & $120 \pm 5.223$ & -0.569 & 0.170 \\
\hline Diastolic BP $6 h$ post CS & $76.25 \pm 5.721$ & $77.08 \pm 7.082$ & -0.810 & 0.420 \\
\hline Pulse 6 h post CS & $71.25 \pm 5.561$ & $73.42 \pm 6.939$ & -2.063 & $0.041^{*}$ \\
\hline Respiration $6 \mathrm{~h}$ post CS & $17.50 \pm 1.127$ & $18.23 \pm .948$ & -0.175 & 0.861 \\
\hline $\begin{array}{l}\text { Cumulative dose of analgesia (morphine) use during the } \\
\text { first } 48 \mathrm{~h} \text { in } \mathrm{mg}\end{array}$ & $1500.235 \pm 19.993$ & $2500.67 \pm 20.773$ & 2.224 & $0.032^{*}$ \\
\hline
\end{tabular}


t: independent sample t test; * significant at 0.05

Table-2 elucidated that there is no statistically significant differences between intervention and control group in relation to their obstetrical history and post-operative vital signs except for pulse. The mean was $71.25 \pm 5.561$ and $73.42 \pm 6.939$ among intervention and control groups respectively for Pulse 6h post CS. For cumulative morphine, use during the first $48 \mathrm{~h}$ the mean is $1500.235 \pm 19.993 \& 2500.67 \pm 20 \mathrm{mg}$ for intervention and control group, respectively. Morphine use is statistically higher among control group than intervention.

Table-3: Percent distribution of the study participants according to incidence and duration of PDPH

\begin{tabular}{|c|c|c|c|c|c|c|c|}
\hline \multirow[t]{2}{*}{ incidence and duration of PDPH } & & \multicolumn{2}{|c|}{ Intervention } & \multicolumn{2}{|c|}{ Control } & \multirow[t]{2}{*}{ Significant test } & \multirow[t]{2}{*}{$P$ value } \\
\hline & & $\mathbf{N}$ & $\%$ & $\mathbf{N}$ & $\%$ & & \\
\hline \multirow{3}{*}{ Operation day } & No headache & 60 & 100.0 & 59 & 98.3 & & \\
\hline & $\begin{array}{l}\text { Intermittent } \\
\text { headache }\end{array}$ & 0 & 0.0 & 1 & 1.7 & FET $=1.359$ & 0.315 \\
\hline & $\begin{array}{l}\text { Continuous } \\
\text { headache }\end{array}$ & 0 & 0.0 & 0 & 0.0 & & \\
\hline \multirow[t]{3}{*}{$1^{\text {st }}$ post-operative day } & No headache & 49 & 81.7 & 38 & 63.3 & & \\
\hline & $\begin{array}{l}\text { Intermittent } \\
\text { headache }\end{array}$ & 8 & 13.3 & 12 & 20.0 & $\mathrm{FET}=5.965$ & $0.05^{*}$ \\
\hline & $\begin{array}{l}\text { Continuous } \\
\text { headache }\end{array}$ & 3 & 5.0 & 10 & 16.7 & & \\
\hline \multirow[t]{3}{*}{$2^{\text {nd }}$ post-operative day } & No headache & 31 & 51.7 & 25 & 41.7 & & \\
\hline & $\begin{array}{l}\text { Intermittent } \\
\text { headache }\end{array}$ & 21 & 35.0 & 13 & 21.7 & $\mathrm{FET}=9.049$ & $0.010^{*}$ \\
\hline & $\begin{array}{l}\text { Continuous } \\
\text { headache }\end{array}$ & 8 & 13.3 & 22 & 36.7 & & \\
\hline \multirow[t]{3}{*}{$3^{\text {rd }}$ postoperative day } & No headache & 31 & 51.7 & 19 & 31.7 & & \\
\hline & $\begin{array}{l}\text { Intermittent } \\
\text { headache }\end{array}$ & 21 & 35.0 & 17 & 28.3 & $\mathrm{FET}=11.301$ & $0.004^{*}$ \\
\hline & $\begin{array}{l}\text { Continuous } \\
\text { headache }\end{array}$ & 8 & 13.3 & 24 & 40.0 & & \\
\hline \multirow[t]{3}{*}{$4^{\text {th }}$ postoperative day } & No headache & 35 & 58.3 & 17 & 28.3 & & \\
\hline & $\begin{array}{l}\text { Intermittent } \\
\text { headache }\end{array}$ & 19 & 31.7 & 23 & 38.3 & $\mathrm{FET}=14.150$ & $0.001^{*}$ \\
\hline & $\begin{array}{l}\text { Continuous } \\
\text { headache }\end{array}$ & 6 & 10.0 & 20 & 33.3 & & \\
\hline \multirow[t]{3}{*}{$5^{\text {th }}$ postoperative day } & No headache & 39 & 65.0 & 26 & 43.3 & & \\
\hline & $\begin{array}{l}\text { Intermittent } \\
\text { headache }\end{array}$ & 17 & 28.3 & 19 & 31.7 & $\mathrm{FET}=14.150$ & $0.001^{*}$ \\
\hline & $\begin{array}{l}\text { Continuous } \\
\text { headache }\end{array}$ & 4 & 6.7 & 15 & 25.0 & & \\
\hline \multirow[t]{3}{*}{$6^{\text {th }}$ postoperative day } & No headache & 46 & 76.7 & 32 & 53.3 & & \\
\hline & $\begin{array}{l}\text { Intermittent } \\
\text { headache }\end{array}$ & 12 & 20.0 & 21 & 35.0 & $\mathrm{FET}=7.745$ & $0.021^{*}$ \\
\hline & $\begin{array}{l}\text { Continuous } \\
\text { headache }\end{array}$ & 2 & 3.3 & 7 & 11.7 & & \\
\hline \multirow[t]{3}{*}{$7^{\text {th }}$ postoperative day } & No headache & 53 & 88.3 & 49 & 81.7 & & \\
\hline & $\begin{array}{l}\text { Intermittent } \\
\text { headache }\end{array}$ & 6 & 10.0 & 9 & 15.0 & $\mathrm{FET}=2.697$ & $0.260^{*}$ \\
\hline & $\begin{array}{l}\text { Continuous } \\
\text { headache }\end{array}$ & 1 & 1.7 & 2 & 3.3 & & \\
\hline
\end{tabular}

FET: Fisher exact test; t: independent sample t test; * significant at 0.05

Table-3 shows that almost all (100\% and $98.3 \%$ ) of intervention and control group, respectively, had no PDPH at operation day without statistically significant differences between the two groups. At the first post-operative day, $81.7 \%$ of the intervention group had no headache compared to $63.6 \%$ of the control group with statistically significant difference between the two groups. Continuous $\mathrm{PDPH}$ is present among $13.3 \%$ of the intervention group compared to $36.7 \%$ of the control group during the $2^{\text {nd }}$ post-operative day. Meanwhile, in the $3^{\text {rd }}$ day the percentage of continues PDPH was the same (13.3\%) in the intervention group but it raised to $40 \%$ of the control group. In the $4^{\text {th }}$ day continues PDPH substantially decreased among intervention group to only $10 \%$ compared to $33.3 \%$ of the control. Later on, during the 4th day, continuous PDPH is decreased between both groups but it is still higher in the control 
group (25\%) compared to intervention (6.7\%). In the $6^{\text {th }}$ day $76.7 \%$ of the intervention group have, no PDPH compared to $53.3 \%$ of the control. Finally, in the $7^{\text {th }}$ post day $10 \%$ of the intervention group compared to $15 \%$ of the intervention group have intermittent headache. The differences between the two groups is statistically significant.

Table-4: Mean differences between intervention and control group in relation to their VAS, McGill Pain score and physical activity limitation due to PDPH

\begin{tabular}{|c|c|c|c|c|c|c|c|c|c|c|c|}
\hline 을 & 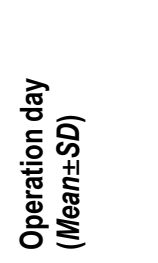 & 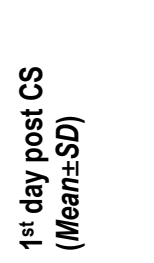 & 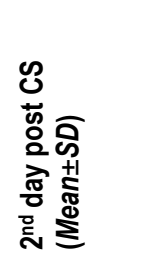 & 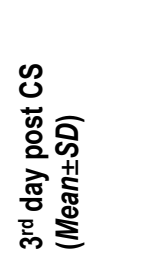 & 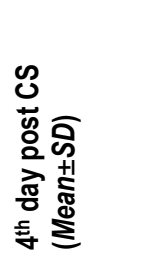 & 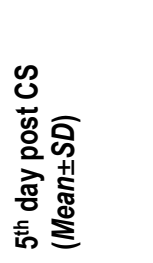 & 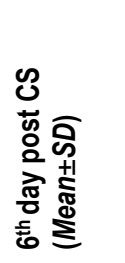 & 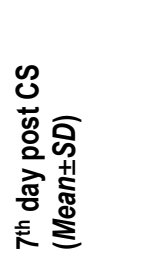 & 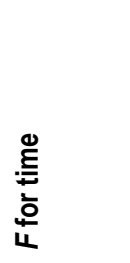 & $\begin{array}{l}\text { 음 } \\
\text { 음 } \\
\frac{2}{0} \\
\frac{0}{4}\end{array}$ & 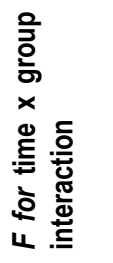 \\
\hline \multicolumn{12}{|l|}{ VAS } \\
\hline $\begin{array}{l}\text { Intervention } \\
(n=60)\end{array}$ & $7.27 \pm 3.262$ & $6.20 \pm 2.950$ & $5.18 \pm 2.678$ & $4.17 \pm 2.464$ & $3.12 \pm 2.309$ & $2.43 \pm 2.028$ & $\begin{array}{l}1.70 \pm 1.56 \\
6\end{array}$ & $0.75 \pm 1.230$ & $\begin{array}{l}F= \\
506.556\end{array}$ & $F=14.536$ & $\begin{array}{l}F=692.05 \\
9\end{array}$ \\
\hline $\begin{array}{l}\text { Control } \\
(n=60)\end{array}$ & $6.57 \pm 2.658$ & $6.43 \pm 2.270$ & $5.47 \pm 2.127$ & $4.70 \pm 2.157$ & $4.05 \pm 1.836$ & $3.42 \pm 1.700$ & $\begin{array}{l}2.50 \pm 1.52 \\
4\end{array}$ & $1.28 \pm 1.530$ & \multirow[t]{2}{*}{$P=0.001^{*}$} & \multirow[t]{2}{*}{$P=0.001^{*}$} & \multirow[t]{2}{*}{$\mathrm{P}=0.000^{*}$} \\
\hline$P$-value & 0.200 & 0.678 & 0.522 & 0.210 & $0.05^{*}$ & $0.05^{*}$ & $0.05^{*}$ & $0.37^{*}$ & & & \\
\hline \multicolumn{12}{|c|}{ Total McGill Pain score } \\
\hline $\begin{array}{l}\text { Intervention } \\
(n=60)\end{array}$ & $\begin{array}{l}23.80 \pm 5.71 \\
9\end{array}$ & $20.88 \pm 5.073$ & $18.03 \pm 4.878$ & $15.70 \pm 4.515$ & $13.17 \pm 4.203$ & $10.72 \pm 3.983$ & $\begin{array}{l}8.20 \pm 3.55 \\
5\end{array}$ & $5.20 \pm 2.736$ & $\mathrm{~F}=412.739$ & $F=14.918$ & $\begin{array}{l}F=631.63 \\
3\end{array}$ \\
\hline Control $(n=60)$ & $\begin{array}{l}23.17 \pm 6.06 \\
8\end{array}$ & $21.98 \pm 5.426$ & $20.53 \pm 5.274$ & $18.78 \pm 4.941$ & $16.90 \pm 4.729$ & $14.58 \pm 4.637$ & $\begin{array}{l}12.35 \pm 4.7 \\
76\end{array}$ & $9.40 \pm 5.143$ & $\mathrm{P}=0.000^{*}$ & $P=0.000^{*}$ & $\mathrm{P}=0.000^{*}$ \\
\hline$P$-value (t test) & 0.557 & 0.254 & $0.008^{*}$ & $0.001^{*}$ & $0.000^{*}$ & $0.000^{*}$ & $0.000^{*}$ & $0.000^{*}$ & & & \\
\hline \multicolumn{12}{|c|}{ Sensory descriptors } \\
\hline $\begin{array}{l}\text { Intervention } \\
(n=60)\end{array}$ & $\begin{array}{l}16.6333 \pm 3 . \\
92716\end{array}$ & $\begin{array}{l}14.9167 \pm 3.7 \\
5654\end{array}$ & $\begin{array}{l}13.3833 \pm 3.5 \\
2757\end{array}$ & $\begin{array}{l}12.1167 \pm 3.3 \\
2475\end{array}$ & $\begin{array}{l}10.5833 \pm 3.3 \\
5115\end{array}$ & $\begin{array}{l}8.8167 \pm 3.31 \\
147\end{array}$ & $\begin{array}{l}6.8500 \pm 3 . \\
10726\end{array}$ & $\begin{array}{l}4.5833 \pm 2.50 \\
621\end{array}$ & $F=19.02$ & $F=408.393$ & $\begin{array}{l}F=1612.5 \\
49\end{array}$ \\
\hline Control $(n=60)$ & $\begin{array}{l}15.4667 \pm 4 . \\
29216\end{array}$ & $\begin{array}{l}14.8667 \pm 4.0 \\
0198\end{array}$ & $\begin{array}{l}14.0333 \pm 3.9 \\
5297\end{array}$ & $\begin{array}{l}13.1833 \pm 3.6 \\
5222\end{array}$ & $\begin{array}{l}12.2000 \pm 3.5 \\
3577\end{array}$ & $\begin{array}{l}10.9500 \pm 3.4 \\
6618\end{array}$ & $\begin{array}{l}9.6000 \pm 3 . \\
61353\end{array}$ & $\begin{array}{l}7.7833 \pm 3.95 \\
779\end{array}$ & $\mathrm{P}=0.001^{\star}$ & $\mathrm{P}=0.000^{*}$ & $P=0.000^{\star}$ \\
\hline$P$-value & 0.123 & 0.944 & 0.344 & $0.097^{*}$ & $0.011^{*}$ & $0.001^{*}$ & $0.000^{*}$ & $0.000^{*}$ & & & \\
\hline \multicolumn{12}{|c|}{ Affective descriptors } \\
\hline $\begin{array}{l}\text { Intervention } \\
(n=60)\end{array}$ & $\begin{array}{l}7.1667 \pm 2.01 \\
828\end{array}$ & $\begin{array}{l}5.9000 \pm 1.46 \\
946\end{array}$ & $\begin{array}{l}4.6500 \pm 1.63 \\
464\end{array}$ & $\begin{array}{l}3.5833 \pm 1.51 \\
032\end{array}$ & $\begin{array}{l}2.5833 \pm 1.16 \\
868\end{array}$ & $\begin{array}{l}1.9000 \pm 1.00 \\
338\end{array}$ & $\begin{array}{l}1.3500 \pm .7 \\
9883\end{array}$ & $\begin{array}{l}.6167 \pm .6131 \\
8\end{array}$ & $\mathrm{~F}=21.224$ & $F=722.462$ & $F=0.951$ \\
\hline Control $(n=60$ & $\begin{array}{l}7.1333 \pm 2.12 \\
704\end{array}$ & $\begin{array}{l}6.7167 \pm 1.96 \\
660\end{array}$ & $\begin{array}{l}6.1500 \pm 1.99 \\
002\end{array}$ & $\begin{array}{l}5.4500 \pm 1.96 \\
085\end{array}$ & $\begin{array}{l}4.6167 \pm 1.94 \\
929\end{array}$ & $\begin{array}{l}3.8000 \pm 1.82 \\
078\end{array}$ & $\begin{array}{l}3.0667 \pm 1 . \\
83992\end{array}$ & $\begin{array}{l}2.1333 \pm 1.87 \\
279\end{array}$ & $P=0.000^{*}$ & $\mathrm{P}=0.001^{*}$ & $\mathrm{P}=0.000^{*}$ \\
\hline$P$-value & 0.930 & $0.011^{*}$ & $0.002^{*}$ & $0.000^{*}$ & $0.000^{*}$ & $0.001^{*}$ & $0.003^{*}$ & $0.000^{*}$ & & & \\
\hline \multicolumn{12}{|c|}{ Physical activity limitation due to PDPH } \\
\hline $\begin{array}{l}\text { Intervention } \\
(\mathrm{n}=60)\end{array}$ & $18.00 \pm 4.190$ & $15.10 \pm 3.423$ & $12.72 \pm 3.289$ & $10.42 \pm 3.004$ & $7.95 \pm 2.547$ & $5.90 \pm 2.454$ & $\begin{array}{l}3.85 \pm 2.47 \\
6\end{array}$ & $1.62 \pm 2.026$ & $\begin{array}{l}F=1304.67 \\
0\end{array}$ & $\mathrm{~F}=4.326$ & $\begin{array}{l}\mathrm{F}=1625.0 \\
95\end{array}$ \\
\hline $\begin{array}{l}\text { Control }(n=60 \\
\text { ) }\end{array}$ & $17.35 \pm 3.839$ & $14.97 \pm 3.360$ & $13.03 \pm 2.893$ & $11.02 \pm 2.771$ & $8.70 \pm 3.005$ & $7.02 \pm 2.777$ & $\begin{array}{l}5.02 \pm 2.91 \\
4 \\
\end{array}$ & $1.70 \pm 3.005$ & $P=0.000^{*}$ & $P=0.014^{*}$ & $P=0.000^{*}$ \\
\hline$P$-value & 0.377 & 0.830 & 0.577 & 0.258 & $0 . .143$ & $0.021^{*}$ & $0.020^{*}$ & 0.859 & & & \\
\hline
\end{tabular}

F: Repeated Anova measure t: independent sample t test *significant at 0.05

Table-4 shows that VAS is statistically higher among control compared to intervention group over four time points starting from the $4^{\text {th }}$ to $7^{\text {th }}$ post-operative days. In addition, Total McGill Pain score is significantly lower among intervention than control group over sixth times points starting from the $2^{\text {nd }}$ to $7^{\text {th }}$ post-operative days. Sensory descriptors of McGill Pain scale is higher among control group compared to intervention group over 5 points of times starting from the $3^{\text {rd }}$ to $7^{\text {th }}$ day. Meanwhile, the affective descriptors of McGill Pain scale is higher among control than intervention group over 7 points of times starting from the $1^{\text {st }}$ to $7^{\text {th }}$ postoperative days. Physical activities limitations due to PDPH is lower in the intervention compared to control groups over two points of times beginning from $5^{\text {th }}$ to $6^{\text {th }}$ post-operative days. The differences between the two groups in VAS, McGill Pain score and physical activities limitations due to PDPH are statistically significant intergroup, intragroup and for group time interactions.

Table-5: Percent distribution of the study participants according to their PDPH aggravating and reliving factors

\begin{tabular}{|c|c|c|c|c|c|c|c|c|c|c|}
\hline \multirow[t]{3}{*}{ PDPH aggravating and reliving factors } & \multicolumn{4}{|c|}{ Intervention } & \multicolumn{4}{|c|}{ Control } & \multirow[t]{3}{*}{ Significance Test } & \multirow[t]{3}{*}{$\mathbf{P}$} \\
\hline & \multicolumn{2}{|c|}{ Yes } & \multicolumn{2}{|c|}{ No } & \multicolumn{2}{|c|}{ Yes } & \multicolumn{2}{|l|}{ No } & & \\
\hline & $\mathbf{N}$ & $\%$ & $\mathbf{N}$ & $\%$ & $\mathbf{N}$ & $\%$ & $\mathbf{N}$ & $\%$ & & \\
\hline \multicolumn{11}{|l|}{ Aggravating factors } \\
\hline - Light & 35 & 58.3 & 25 & 41.7 & 51 & 85.0 & 9 & 15.0 & $X^{2}=10.506$ & $0.001^{*}$ \\
\hline - Noise & 32 & 53.3 & 28 & 46.7 & 43 & 71.7 & 17 & 28.3 & $X^{2}=4.302$ & $.038^{*}$ \\
\hline - $\quad$ Standing & 47 & 78.3 & 13 & 21.7 & 57 & 95.0 & 3 & 5.0 & $\mathrm{FET}=7.212$ & $0.007^{*}$ \\
\hline - Moving & 49 & 81.7 & 11 & 18.3 & 56 & 93.3 & 4 & 6.7 & $\mathrm{FET}=2.911$ & $0.049^{*}$ \\
\hline - $\quad$ Siting & 31 & 51.7 & 29 & 48.3 & 42 & 70.0 & 18 & 30.0 & $X^{2}=4.23$ & $0.040^{*}$ \\
\hline - $\quad$ Hunger & 9 & 15.0 & 51 & 85.0 & 11 & 18.3 & 49 & 81.7 & $X^{2}=0.240$ & 0.628 \\
\hline
\end{tabular}




\begin{tabular}{|c|c|c|c|c|c|c|c|c|c|c|c|}
\hline- & Thirsty & 15 & 25.0 & 45 & 75.0 & 10 & 16.7 & 50 & 83.3 & $X^{2}=0.768$ & 0.375 \\
\hline- & Speaking & 19 & 31.7 & 41 & 68.3 & 15 & 25.0 & 45 & 75.0 & $X^{2}=0.657$ & 0.418 \\
\hline \multicolumn{12}{|c|}{ Reliving factors } \\
\hline- & Lying down & 58 & 96.7 & 2 & 3.3 & 57 & 95.0 & 3 & 5.0 & $\mathrm{FET}=0.210$ & 0.648 \\
\hline- & Closing eyes & 47 & 78.3 & 13 & 21.7 & 45 & 75.0 & 15 & 25.0 & $X^{2}=0.186$ & 0.666 \\
\hline- & Diverting attention & 14 & 23.3 & 46 & 76.7 & 9 & 15.0 & 51 & 85.0 & $X^{2}=1.875$ & 0.171 \\
\hline- & Drinking fluids & 50 & 83.3 & 10 & 16.7 & 48 & 80.0 & 12 & 20.0 & $X^{2}=0.223$ & 0.637 \\
\hline- & Eating & 35 & 58.3 & 25 & 41.7 & 32 & 53.3 & 28 & 46.7 & $X^{2}=0.304$ & 0.581 \\
\hline
\end{tabular}

$\mathrm{X}^{2}$ : Chi-square test; FET: Fisher exact test; t: independent sample t test; ${ }^{*}$ significant at 0.05

Table-5 showed that PDPH is more aggravated by light, noise, standing, moving and siting in control groups than intervention groups with statistically significant differences between them. Furthermore, laying down, closing eyes, drinking fluids are major soothing factors for PDPH in both groups without statistically significant differences between them.

\section{Discussion}

Generally, PDPH is a serious complication that commonly occurs after spinal anesthesia. Conservative management of PDPH involves extensive hydration, bed rest without pillow, psychological assurance and vasoconstrictors such as caffeine. Coffee is the most popular source of oral caffeine [22]. Drinking coffee to manage PDPH is acceptable nursing intervention that have no side effect. If it is proved to be effective, it will provide safe, effective, easy, cheap and acceptable PDPH treatment option. Therefore, this study aims to investigate the effect of coffee consumption on the incidence and severity of PDPH among post cesarean section women.

The current study results shows that the incidence and severity of PDPH is higher among control than intervention group. While, the maximum incidence of continuous PDPH occurs in the third post-operative day among control group (40\%) compared to only $13.3 \%$ among intervention. In addition, both continuous and intermittent PDPH recovered faster in the coffee compared to control group. Finally, in the $7^{\text {th }}$ post day only $10 \%$ of the intervention group compared to $15 \%$ of the intervention group have intermittent headache. Both VASand McGill Pain score is statistically higher among control compared to intervention group over several time points. The differences between the two groups in VAS and McGill Pain score are statistically significant intergroup, intragroup and for group time interactions.

The result of the current study is consistent with at least six other studies. First, Ali [23] who studied effect of nursing intervention tension headache incidence among surgical patients undergoing spinal anesthesia in Egypt. They confirmed that there was a true reduction in the duration of tension headache in the intervention group compared to control. In addition, PDPH intensity is significantly lower among intervention group compared to control group. Second, Masoudifar et al., [24] who conducted a research to combined caffeine with acetaminophen and dexamethasone medication in the treatment of PDPH. They reported that $53.3 \%$ of their study group reported the incidence of PDPH compared to only $37.7 \%$ of the control group. The differences between the two groups was not statistically significant. They further added that headache frequency was registered 35 times in the control group compared to 27 among intervention group. They concluded that their intervention decreased both incidence and duration of PDPH without statistical significant difference between the two groups. Third, Babatunde O, \& Adebola G [25] who conducted evidence based review of primary health care practices in the management of PDPH. They elaborated that caffeine gives temporally non-sustainable relive from PDPH, therefore, repeated dose over the day is urgent. Fourth, Ragab and Facharzt [26] who investigated the effect of $500 \mathrm{mg}$ IV caffeine injection of the incidence and severity of PDPH among patient undergoing elective knee surgery. They reported lower incidence and severity of PDPH among caffeine injection group compared to control. They concluded that caffeine might be recommended therapy for PDPH. Fifth, Eshghizadeh et al., [27]. They performed randomized controlled clinical trial on 140 women undergoing caesarian section in Razi hospital at Torbat Heidarieh. Their study group consumed four cups of instant coffee divided on two dose daily. Each time the woman take two cups with an hour space. They reported that PDPH occurred among only $15.7 \%$ of the coffee group compared to only 37.1 of the control. Furthermore, the intensity of headache was more sever in the control compared to coffee group. The differences in PDPH incidence and severity were statistically significant between coffee and control group. Sixth, Zeger et al., [28] who compared the effect of caffeine injection tocosyntropin in management of PDPH among adult patents who came to emergency department. They found that caffeine was effective as cosyntropin in PDPH management.

The present study results is also in line with current literatures. Turnbull et al., [29] reported in his review that caffeine have cerebral vasoconstrictive effect that can help in reducing PDPH. They further added that caffeine is proved to be effect in both IV and oral form. Although, oral caffeine is absorbed and produce its peak effect after only 30 min and its half-life is around $3 \pm 7.5$ hours. They further recommended that PDPH can be managed by 2-3 cups of coffee daily.in addition, Shibli K et al., [30] had reported the same beneficial effect of caffeine for PDPH management. However, they raised the dose required to reach $500 \mathrm{mg} / 8 \mathrm{hours}$ (1500 $\mathrm{mg} / 24)$. This may raise safety concern because high dose of caffeine is associated with serious side effect. It is proved that $500 \mathrm{mg} /$ day is safe and effective dose for PDPH. 
The present study results are incongruent with Lin et al., [31] who wrote an article about the myths of using caffeine, bed rest and intravenous fluids for the treatment of PDPH. They did not perform a study to investigate the effect of caffeine on PDPH but they criticize some old studies. Furthermore, they did not did not elaborate the physiological base of their critique. Furthermore, Esmaoghla et al., [32] who compared two doses of caffeine combined with paracetamol for the management of PDPH among patients undergoing lower extremities surgery. They concluded that there is no statistically significant differences between the two groups and control in term of PDPH incidence and severity. In addition, no signs of caffeine excess appeared among their participants. The differences between the current study results and that of Esmaoghla et al., [32] might be due to the difference in intervention. Where, they combined paracetamol with different doses of caffeine while the present study used caffeine only. Furthermore, their participants conducted lower extremities surgery where, the present study conducted on post CS woman.

The study findings revealed that PDPH is more aggravated by light, noise, standing, moving and siting in control than intervention groups with statistically significant differences between them. Furthermore, laying down, closing eyes, drinking fluids are major soothing factors for PDPH in both groups without statistically significant differences between them.

These findings are consistent with Turnbull et al., [29] \& Bezov et al., [33] The former discussed the pathogenesis and aggravating factors associated with PDPH. They reported that PDPH is aggravated by standing, siting in upright position and head movement. They further added that laying down decreased the severity of PDPH. They further added that PDPH is decreased with supine position, increasing fluid intake and complete bed rest. This finding is confirmed by physiological decrease in cerebra pressures that occurs in upright position. The latter, Bezov et al., [33] reported that patients complains of severe headache, characteristically located in the frontal and or the occipital region. The pain is worsened with the upright position and improves with lying down.They further added that PDPH is aggravated with any increase in intracranial pressure associated with coughing, peering down or sneezing. Other studies reported the same results [34, 35].

The highest percentages of patients in study (Coffee) group had no effect on activity of daily living compared to patients in control group. This result may be due to the fact that coffee increases energy, alertness, ability to concentrate, decreases fatigue and pain. Awareness of caffeine properties that enhance alertness, energy may encourage its use in the management of PDPH. In line with the current study is that of Karen et al., [36] who studied the effect of caffeine on activity of sedentary women. They reported that caffeine use significantly enhanced energy expenditure and average power. They further added that caffeine significantly decreased perceived exertion rate among their participates at time of maximum activity. This effect occurred after ingestion of $6 \mathrm{mg}$ of caffeine for each $\mathrm{kg}$ of body weight. The result of the current study seems to be logic. As, if the severity and frequency of PDPH is decreased, the woman physical activities will be improved. Therefore, if coffee significantly decreased PDPH incidence and severity physical activities will be improved. Coffee increases energy, alertness, ability to concentrate and decreases fatigue. Awareness of caffeine properties that enhance alertness, energy may encourage its use in the management of PDPH after Cs.

\section{CONCLUSION}

Based on the current study results $\mathrm{H} 1$ is accepted. The incidence and severity of PDPH is higher among control than coffee group. While, the maximum incidence of continuous PDPH occurs in the third post-operative day among control group (40\%) compared to only $13.3 \%$ among intervention. Both VAS and McGill Pain score are statistically higher among control compared to intervention group over several time points. PDPH is aggravated by light, noise, standing, moving and siting in control groups than intervention groups. Laying down, closing eyes, drinking fluids are major soothing factors. The highest percentages of coffee group had no effect on activity of daily living compared to control group.The differences between the two groups are statistically significant intergroup, intragroup and for group time interactions.

\section{RECOMMENDATIONS}

Oral coffee may be added to post Cs nursing care protocols to decrease PDPH incidence, severity and enhancing early physical activities.

\section{REFERENCE}

1. El-Zanaty and Associates. (2015). Egypt demographic and health survey 2015. Ministry of Health and Population Cairo, Egypt. The DHS Program ICF International Rockville, Maryland, USA. Available at: https://dhsprogram.com/pubs/pdf/fr302/fr302.pdf. Reviewed on:13/7/2019.

2. Erol, D., \& Aytac, I. (2018). Current anesthesıa for Cesarean Section. Clinical Journal of Obstetrics and Gynecology Open. 1(5):61-66.

3. Abdel-Tawab, N. G., Oraby, D., Hassanein, N., \& El-Nakib, S. (2018). Cesarean section deliveries in Egypt: Trends, practices, perceptions, and cost. Population Council - Egypt Office. Available at: https://www.popcouncil.org/uploads/pdfs/2018PGY_cesareansectionegypt.pdf. Reviewed on: 22/7/2019.

4. Gielen, M. (1989). Post Dural puncture headach (PDPH): A review. Reg Anesth, 14(3):101-106. 
5. Smith, J. H., Mac Grory, B., Butterfield, R. J., Khokar, B., Falk, B. L., \& Marks, L. A. (2019). CSF Pressure, Volume, and PostDural Puncture Headache: A Case-Control Study and Systematic Review. Headache: The Journal of Head and Face Pain, 59(8), 1324-1338.

6. Sprigge, J. S., \& Harper, S. J. (2008). Accidental dural puncture and post dural puncture headache in obstetric anaesthesia: presentation and management: a 23-year survey in a district general hospital. Anaesthesia, 63(1), 36-43.

7. Bhat, M. T., \& Hegde, B. K. (2017). Spinal anaesthesia for caesarean section: Comparison of 25G Whitacre needles with $25 \mathrm{G}$ and 23G Quincke needles for technical problems and post-operative complications. Indian Journal of Clinical Anaesthesia, 4(2), 202-207.

8. Lybecker, H., Møller, J. T., May, O., \& Nielsen, H. K. (1990). Incidence and prediction of postdural puncture headache. A prospective study of 1021 spinal anesthesias. Anesthesia and analgesia, 70(4), 389-394.

9. Nath, G., \& Subrahmanyam, M. (2011). Headache in the parturient: pathophysiology and management of post-dural puncture headache. Journal of obstetric anaesthesia and critical care, 1(2):57-66.

10. Ahmed, S. V., Jayawarna, C., \& Jude, E. (2006). Post lumbar puncture headache: diagnosis and management. Postgraduate medical journal, 82(973), 713-716.

11. Griffiths, R. R., \& Woodson, P. P. (1988). Reinforcing properties of caffeine: studies in humans and laboratory animals. Pharmacology Biochemistry and Behavior, 29(2), 419-427.

12. Griffiths, R. R., \& Woodson, P. P. (1988). Caffeine physical dependence: a review of human and laboratory animal studies. Psychopharmacology, 94(4), 437-451.

13. Gogarten, W., \& Van Aken, H. (2000). A century of regional analgesia in obstetrics. Anesthesia \& Analgesia, 91(4), 773-775.

14. Brown, D. (2005). Spinal, epidural and caudal anesthesia. In: Miller RD, ed. Miller's Anesthesia. 6th edition. Philadelphia: Churchill Livingstone, 1653-1679.

15. Nehlig, A. (2016). Effects of coffee/caffeine on brain health and disease: What should I tell my patients?. Practical Neurology, 16(2):89-95.

16. Chrysant, S. (2015). Coffee Consumption and Cardiovascular Health. American journal of cardiology, 116(5):818-821.

17. Utami, Y., \& Hasan, I. (2015). Coffee Consumption to Reduce Liver Fibrosis. The Indonesia journal of gastroenterology, hepatology and digestive endoscopy. 16(1): 41-46.

18. Rachel, R., Bruce, A., \& Edward, J. (2003). Caffeine Content of Specialty Coffees. Journal of analytical toxicology, 5(27):520522.

19. McCormack, H. M., David, J. D. L., \& Sheather, S. (1988). Clinical applications of visual analogue scales: a critical review. Psychological medicine, 18(4), 1007-1019.

20. Melzack, R. (1987). The short-form McGill pain questionnaire. Pain, 30(2), 191-197.

21. McCusker, R. R., Goldberger, B. A., \& Cone, E. J. (2003). Caffeine content of specialty coffees. Journal of analytical toxicology, 27(7), 520-522.

22. Carlo Tenore, G., Daglia, M., Orlando, V., Urso, E., Hassan Saadat, S., Novellino, E., ... \& Mohammad Nabavi, S. (2015). Coffee and depression: a short review of literature. Current pharmaceutical design, 21(34), 5034-5040.

23. Ali, Z. (2012). Effect of Pre and Post Nursing Intervention on the Occurrence of Tension Headache among Surgical Patients Undergoing Spinal Anesthesia. Journal of Anesthesia \& Clinical Research, 3(7): 2-5.

24. Masoudifar, M., Aghadavoudi, O., \& Adib, S. (2016). Effect of venous dexamethasone, oral caffeine and acetaminophen on relative frequency and intensity of postdural puncture headache after spinal anesthesia. Advanced biomedical research, 5(66):1 6.

25. Omole, O. B., \& Ogunbanjo, G. A. (2015). Postdural puncture headache: evidence-based review for primary care. South African Family Practice, 57(4), 241-246.

26. Ragab, A., \& Facharzt, K. N. (2014). Caffeine, Is it effective for prevention of postdural puncture headache in young adult patients?. Egyptian Journal of Anaesthesia, 30(2), 181-186.

27. Eshghizadeh, M., Moghadam, M. B., Pour, A. M., \& Hashemi, Z. S. B. (2015). The effect of coffee consumption on the headache caused by spinal anesthesia for cesarean section. Avicenna Journal of Phytomedicine, 2(5): 34-39.

28. Zeger, W., Younggren, B., \& Smith, L. (2012). Comparison of cosyntropin versus caffeine for post-dural puncture headaches: a randomized double-blind trial. World journal of emergency medicine, 3(3):182-185.

29. Turnbull, D. K., \& Shepherd, D. B. (2003). Post-dural puncture headache: pathogenesis, prevention and treatment. British journal of anaesthesia, 91(5), 718-729.

30. Shibli, K. U., \& Macachor, J. D. (2019). What works for the management of PDPH; is the current evidence enough?. Anaesthesia, Pain \& Intensive Care, 137-141.

31. Lin, W., \& Geiderman, J. (2002). Myth: fluids, bed rest, and caffeine are effective in preventing and treating patients with postlumbar puncture headache. Western journal of medicine, 176(1):69-70.

32. Esmaoglu, A., Akpinar, H., \& Uğur, F. (2005). Oral multidose caffeine-paracetamol combination is not effective for the prophylaxis of postdural puncture headache. Journal of clinical anesthesia, 17(1), 58-61.

33. Bezov, D., Lipton, R. B., \& Ashina, S. (2010). Post-dural puncture headache: part I diagnosis, epidemiology, etiology, and pathophysiology. Headache: The Journal of Head and Face Pain, 50(7), 1144-1152. 
34. Alam, M. R., Raheen, M. R., Iqbal, K. M., \& Chowdhury, M. R. A. (2011). Headache following spinal anaesthesia: a review on recent update. Journal of Bangladesh College of Physicians and Surgeons, 29(1), 32-40.

35. Lavi, R., Yernitzky, D., Rowe, J. M., Weissman, A., Segal, D., \& Avivi, I. (2006). Standard vs atraumatic Whitacre needle for diagnostic lumbar puncture: a randomized trial. Neurology, 67(8), 1492-1494.

36. Wallman, K. E., Goh, J. W., \& Guelfi, K. J. (2010). Effects of caffeine on exercise performance in sedentary females. Journal of sports science \& medicine, 9(2), 183-189. 